\title{
A estratégia geopolítica brasileira para o Atlântico Sul
}

\author{
Bruno Gomes Guimarães
}

\begin{abstract}
Resumo: Este artigo procura explicar a estratégia geopolítica brasileira para o Atlântico Sul, desde 2000. Para isso, apresentamse os contornos gerais da inserção internacional brasileira e das relações bilaterais e multilaterais do Brasil com países sul-atlânticos e potências extrarregionais. Também se trabalha com as políticas domésticas. Concluise que a estratégia brasileira é de caráter defensivo, visando à proteção de sua soberania e integridade territorial.
\end{abstract}

Palavras-chave: Atlântico Sul; Brasil; Geopolítica.

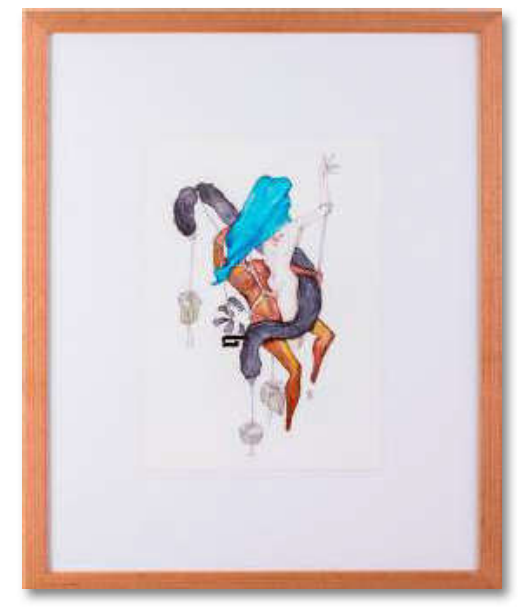

\section{Brazilian geopolitical strategy for the South Atlantic}

Abstract: This paper sought to explain the Brazilian geopolitical strategy for the South Atlantic since 2000. For this purpose, the general outlines of Brazil's international insertion and Brazilian bilateral and multilateral relations with South Atlantic countries and extra-regional powers were presented. Domestic policies were also taken into consideration. In conclusion, the Brazilian strategy is defensive, aiming to protect its sovereignty and territorial integrity.

Doutorando em Estudos Estratégicos Internacionais da Universidade Federal do Rio Grande do Sul. Professor de Direito Internacional no Centro Universitário Ritter dos Reis. Editor-chefe e pesquisador do Instituto Sul-Americano de Política e Estratégia.bgguima@gmail.com Geopolitics.

$$
\text { ReCEBIDO EM: } 0 \overline{2 \text { DE AGOSTO DE } 2015}
$$

Aprovado EM: 25 DE SETEMBRO DE 2015
Keywords: South Atlantic; Brazil. 
Bruno Gomes Guimarães

\section{INTRODUÇÃO'}

O oceano Atlântico Sul está passando por um momento de crescente importância internacional. Existem muitas descobertas recentes de recursos minerais, na sua bacia, que trazem antigas disputas territoriais de volta para a agenda internacional. Além disso, a crescente limitação das capacidades dos canais do Panamá e de Suez (que não suporta supercargueiros) aumenta a relevância das rotas do Atlântico Sul, de maneira geral.

O Brasil é um ator crucial, neste cenário, graças à posse da maior fronteira marítima do Atlântico Sul. O Brasil possui quase $7500 \mathrm{~km}$ de costa no Atlântico, tendo $80 \%$ da sua população habitando as regiões próximas ao mar, e 95\% do comércio internacional brasileiro é transportado pelas rotas sul-atlânticas (WIESEBRON, 2013). Muitos recursos naturais foram descobertos na Zona Econômica Exclusiva (ZEE) brasileira, onde destaca-se a importância dos hidrocarbonetos encontrados nas águas profundas do Atlântico Sul, em 2006 (o "Pré-Sal"). Utilizando toda a sua capacidade de operação, essas reservas fariam do Brasil um dos dez maiores produtores de petróleo do mundo (WIESEBRON, 2013).

O Brasil gradualmente destaca-se por seu papel no sistema internacional e, como uma potência emergente, é importante analisar se sua ascensão será pacífica ou não. Isso explica por que observar a estratégia geopolítica brasileira é vital para a compreensão da evolução do sistema internacional como um todo. Esse estudo pretende focar-se na estratégia geopolítica brasileira e em suas políticas para o Atlântico Sul, trabalhando para explicar seus projetos para o oceano, desde o ano 2000, enquanto leva em consideração sua ascensão no cenário internacional.

Esta pesquisa irá extrair a abordagem teórica de Therezinha de Castro (2002) de uma "oceanopolítica" (termo cunhado em oposição à "geopolítica") e a conceituação de Julian Corbett (1911)

1 Agradeço os valiosos comentários feitos por colegas pesquisadores(as) Marcela Ávila, Julian Fitz, Jéssica Höring, Giovana Zucatto, João Arthur Reis, David Ramin Jalilvand e Iara Binta Machado e à assistência do Prof. Lucas Kerr e da Prof ${ }^{a}$. Analúcia Pereira. Também fica o agradecimento para os pertinentes comentários dos(as) pareceristas de Tensões Mundiais. 
para a estratégia naval. ${ }^{2}$ A hipótese trabalhada é a de que o Brasil busca o comando geral do Atlântico Sul, mas ainda não possui as condições necessárias para esse propósito. Para alcançar esse objetivo, o Brasil estaria empenhando-se para estabelecer bases militares e reforçar a cooperação naval, em regiões estratégicas no Atlântico Sul, enquanto trabalha para restringir a presença de atores extrarregionais.

\section{MARCO TEÓRICO}

Castro (2002) atesta que existem muitas maneiras de delimitar o Atlântico Sul, especialmente levando em consideração sua parte norte. Para ela, o formato mais prático seria considerar a extremidade norte do Atlântico sul como o ponto de estrangulamento entre Natal, cidade localizada na saliência do nordeste brasileiro, e Dakar, no Senegal, a cidade subsaariana mais ao norte da África Ocidental. Porém, delimitações históricas encaixam-se melhor para a compreensão da geopolítica. Regiões de colonização portuguesa devem ser consideradas como um conjunto. Consequentemente, o limite norte do Atlântico Sul seria entre o ponto mais ao norte da costa brasileira (no Amapá) e de Cabo Verde. Os limites ao sul, leste e oeste são de fácil definição: a Antártida, o Cabo da Boa Esperança e os estreitos de Beagle/ Magalhães/Drake, respectivamente (CASTRO, 2002).

As correntes marítimas do Atlântico Sul, embora não tão poderosas quanto as do Atlântico Norte, são circuitos de conexão natural entre a África e a América do Sul. Sua importância para as rotas marítimas tem sido vital, desde a colonização portuguesa, que interligou Brasil, Angola e o Golfo da Guiné. ${ }^{3}$ Além disso, as ilhas

2 Além das qualidades inerentes à abordagem de Therezinha de Castro, particularmente a respeito da geopolítica brasileira e sul-atlântica, escolhi valorizar seu quadro de análise, porque ele se destaca ao ser uma contribuição de uma mulher civil, em um campo de estudo amplamente dominado pelos escritos de homens e membros das Forças Armadas, tais como os bastante conhecidos generais Golbery do Couto e Silva e Carlos de Meira Mattos.

3 As principais cidades que são interligadas pelas correntes do Atlântico Sul são Luanda (Angola), São Tomé (São Tomé e Príncipe), Rio de Janeiro, Salvador e Recife (Brasil). Recife é particularmente importante, devido à sua localização, 
Bruno Gomes Guimarães

do Atlântico Sul são "trampolins securitários", que dão suporte a essas rotas marítimas (CASTRO, 2002).

Castro (2002) identifica três "trampolins insulares", que têm sido historicamente vitais para o comando do Atlântico Sul, desde Portugal das Grandes Navegações, no final do século XV, até os dias atuais, para países como o Reino Unido e os EUA. O primeiro, que consiste em um triângulo entre as ilhas de Ascensão, Santa Helena e Tristão da Cunha, é vital para a rota rumo ao Oceano Índico e garante projeção de poder na África subsaariana. O segundo é composto pelas ilhas de Fernando de Noronha, Trindade e Malvinas/Falkland, que contribuem para o controle das rotas para o Pacífico e para o estreito de Beagle/Magalhães, assim como para incursões na América do Sul. ${ }^{4} \mathrm{O}$ terceiro trampolim é mais perto da Antártida, ainda que interpenetre os outros dois. Ele, na verdade, desafia a preponderância dos continentes sul-americano e africano com relação às suas rotas. As ilhas de Shetland, South Sandwich, Gough e Geórgia do Sul o compõem.

Assim, três amplas regiões estratégicas podem ser identificadas para o domínio do Atlântico Sul. Primeiro, há a região entre o nordeste brasileiro e a África Ocidental (particularmente Cabo Verde e Senegal), que consiste num ponto de estrangulamento naval entre a América do Sul e a África. Segundo, há os três trampolins insulares, devido à sua importância para as rotas sul-atlânticas. Por fim, há as costas brasileira e africana, especialmente entre Angola e o Golfo da Guiné, no leste, até Recife e Rio de Janeiro, no oeste, considerando que esses são interconectados pelas correntes do Atlântico Sul. Consequentemente, a estratégia para o comando do oceano deve levar esses fatores em consideração.

Corbett (1911) percebeu que a guerra naval não existe destituída do contexto de disputas em terra. A estratégia marítima, portanto, deve ser baseada no pressuposto de que a guerra no mar é uma parte da guerra em terra. O comando do mar está ligado à utilização do mesmo na conquista de objetivos bélicos e existe

onde a corrente que vem da África se divide: uma indo para o norte, em direção ao Caribe, e outra indo para o Sul, em direção ao Rio de Janeiro (ALENCASTRO, 2000). 4 Fernando de Noronha também é estrategicamente significante para a projeção de poder das Américas para a África Ocidental (CASTRO, 2002). 
somente em estado de guerra: "Se afirmamos que temos comando do mar em um momento de paz, afirmamos retoricamente que temos posições navais adequadas; uma frota adequada para proteger o comando quando em guerra" (CORBETT, 1911, p. 318, em tradução própria).

Além disso, Corbett (1911) não acredita que o comando do mar signifique completa destruição da frota inimiga. Para ele, comandar o mar não significa ter liberdade de ação ilimitada no mar ou obter o controle de determinadas águas territoriais. Como Proença Jr., Diniz e Raza (1999) apontam, a ideia de comando do mar de Corbett é circunstancial, baseada na habilidade de utilizar o mar e não em obter seu domínio completo. Portanto:

\begin{abstract}
Comandar o mar não significa que o inimigo não possa fazer absolutamente nada, mas sim garantir que ele não possa seriamente interferir com os empreendimentos pelos quais procuramos assegurar nossos objetivos de guerra, ou impor nossa vontade sobre ele (CORBETT, 1911, p. 318, [tradução própria e ênfase no original]).
\end{abstract}

Em outras palavras, para Corbett (1911), comandar o mar significa impedir que o oponente significativamente obstrua a guerra ou as atividades comerciais. O inimigo até pode ter uma frota ativa, mas ele é incapaz de mudar o curso da guerra ou das decorrências políticas.

Seguindo essa definição, o autor considera que o comando do mar pode ser temporário ou permanente, assim como geral ou local. Comando temporário é quando um ator é capaz de prevenir que um inimigo interfira em uma operação ou campanha particular, durante o período necessário para a mesma (CORBETT, 1911). Em contrapartida, o comando permanente não considera o tempo, ou seja, "quando a possibilidade do inimigo recuperar sua posição marítima é muito remota para tornar-se uma consideração prática" (CORBETT, 1911, p. 319). O comando geral do oceano é alcançado quando o inimigo não é mais capaz de obstruir perigosamente as linhas de passagem e comunicação nem de se defender. Já o comando local implica um dos lados ser capaz de prevenir a interferência do inimigo, em um ou mais teatros de operação específicos. 
Bruno Gomes Guimarães

Combinando os trabalhos de Corbett (1911) e Castro (2002), o comando geral do Atlântico Sul se expressa pelo controle dos trampolins insulares, que bastam para a manutenção de rotas marítimas. Essas ilhas são suficientes para garantir rotas no Atlântico Sul e para interferir no seu uso por outras forças. Atualmente, o Reino Unido possui a maioria dos trampolins insulares, que também são utilizados pelos Estados Unidos como bases militares. Como ambos costumam trabalhar juntos em tópicos militares, esses dois países são considerados comandantes gerais do oceano (PENHA, 2011). Logo, a estratégia brasileira para o comando do Atlântico Sul, como abordamos na nossa hipótese, teria que considerar reduzir a presença de Washington e de Londres no oceano e, de alguma maneira, adquirir instalações nessas ilhas. Em outras palavras, o Brasil buscaria o comando geral e permanente do oceano.

\section{A ESTRATÉGIA DE INSERÇÃO INTERNACIONAL DO BRASIL}

No século XXI, a inserção estratégica internacional do Brasil tem privilegiado dois pontos principais. A integração regional está no seu cerne. Em 2000, depois de uma série de crises econômicas que perturbaram os países da América do Sul, ao final dos anos 1990, o presidente Fernando Henrique Cardoso (1995-2002) fez a escolha anti-intuitiva de aprofundar o processo de integração regional. Quando o MERCOSUL parecia estar falindo, as políticas brasileiras buscaram a integração como uma forma de escapar da crise econômica no bloco: eles não seriam tão dependentes de países estrangeiros quanto anteriormente, i.e. eles diminuiriam sua vulnerabilidade a mercados estrangeiros através da integração (VIZENTINI,2005). Cardoso não só tentou interligar os Estadosmembros do MERCOSUL, mas também buscou estabelecer um processo de integração continental, que culminaria, anos mais tarde, na União das Nações Sul-Americanas (UNASUL), no governo Lula.

Apesar de suas diferentes inclinações políticas, ambos compartilharam a percepção de que a América do Sul deveria estar no centro da inserção internacional estratégica brasileira (embora Cardoso o tenha feito somente em seus últimos anos de mandato). 
O presidente Lula, durante seus oito anos de governo, teve mais tempo para desenvolver essa estratégia, que também foi seguida pela ex-presidente Dilma Rousseff. ${ }^{5}$ Em termos práticos, sob seu governo, o país forjou sua condição de liderança, através da integração sul-americana e da renovação do MERCOSUL. Negociações internacionais também foram fortemente afetadas pelo bloco sul-americano, que pôde barganhar mais com países desenvolvidos. De acordo com Vizentini (2005), a prioridade dada à integração sul-americana ofereceu a todos os países vizinhos a parceria necessária para retomar o crescimento econômico e efetivamente reverteu a tendência global de marginalização da região. Integração continental seria a única estratégia global para todos os países que garantiria o desenvolvimento e a governabilidade na América do Sul e também seria um instrumento necessário para negociações com outros países (VIZENTINI, 2005; 2007).

Através disso, o Brasil ganharia mais peso no cenário internacional, pois, junto aos países da América do Sul, poderia barganhar e conseguir mais do que negociando só. A ideia por trás disso é que o futuro do Brasil está ligado ao futuro de seus vizinhos e essa seria a única maneira de o país ter um papel maior na política mundial. De fato, considerando que uma nova balança de poder multipolar está tomando forma, o Brasil tenta consolidar uma América do Sul unida, que seja pacífica e estável. Silva (2013) e Amorim (2013) argumentam que, se isso for alcançado, o continente se tornaria um novo polo do mundo multipolar.

Portanto, a integração sul-americana encarna três objetivos brasileiros (STUENKEL, 2013). O primeiro é transformar a região em um escudo contra choques e interferências externas, sejam políticos ou econômicos. Por exemplo, uma maior integração de mercados sul-americanos poderia proteger o Brasil (e demais países da região) da competição injusta, seja da China seja de outro país. Similarmente, a interferência política dos EUA nos assuntos

5 O ministro das Relações Exteriores do governo de Michel Temer, José Serra, parece ter abandonado a cordialidade regional e começado a implementar uma política externa em que a América do Sul não é mais central (CASARÕES, 2016; REZENDE, 2016). 
Bruno Gomes Guimarẽes

da região poderia ser evitada, se os países estiverem dispostos a resolver seus problemas por conta própria. O segundo objetivo é a criação de um ambiente estável e pacífico que permita um maior desenvolvimento do continente. Para isso, o Brasil assume a liderança regional e as responsabilidades que disso advêm. Stuenkel (2013) afirma que o Brasil pode estar até mesmo pronto para agir unilateralmente para garantir a estabilidade regional. Porém, há uma forte preferência pela ação coletiva, para resolver os problemas sul-americanos. Finalmente, o terceiro objetivo é o uso da integração regional, como uma plataforma para se tornar uma potência mundial. Se o Brasil for visto como o líder da América do Sul integrada, seu peso em assuntos internacionais seria, sem dúvida, maior, bastante próximo à condição de potência global.

Ao lado da integração regional, a segunda parte da estratégia de inserção internacional brasileira, desde 2000, é a ideia de estabelecer relações mais próximas com outros países em desenvolvimento, para, com isso, diversificar parcerias globais. Nas palavras do ex-ministro das Relações Exteriores e ex-ministro da Defesa Celso Amorim:

$\mathrm{Na}$ intersecção de todas as principais diretrizes da política externa brasileira está o esforço de estabelecer relações mais próximas com outros países em desenvolvimento. A cooperação Sul-Sul é uma estratégia diplomática que advém de um desejo autêntico de exercer solidariedade junto a países mais desfavorecidos. Ao mesmo tempo, ela ajuda a expandir a participação do Brasil em assuntos mundiais. A cooperação entre iguais em temas de comércio, investimento, ciência e tecnologia e outros campos reforça nossa envergadura e fortalece nossa posição em negociações comerciais, financeiras e climáticas. Em último lugar, mas não menos importante, a construção de coalizões com países em desenvolvimento também é um modo de engajar-se na reforma da governança global com o intuito de fazer com que as instituições internacionais sejam mais justas e democráticas (AMORIM, 2010, p. 231, [tradução própria]). 
Na prática, o Brasil procurou parceiros fora do hemisfério ocidental para ampliar sua influência no cenário internacional, através de uma postura mais ativa e pragmática. Então, o Brasil usa a cooperação Sul-Sul para balancear sua inserção internacional vis-à-vis com países desenvolvidos e fluxos de capitais internacionais. Isso não significa que o país tenha ignorado suas relações com o mundo desenvolvido nem que tenha abandonado regimes internacionais já estabelecidos, mas sim que as relações Sul-Sul foram utilizadas para contrabalançar o poder exercido por países desenvolvidos, na política mundial, especialmente em instituições como as Nações Unidas e a Organização Mundial do Comércio (OMC).

Dessa forma, as relações do Brasil com países africanos são essenciais para sua estratégia, porque vinculam princípios éticos e interesses nacionais (VIZENTINI, 2005). Ademais, as relações com outras potências emergentes (OS BRICS, ${ }^{6}$ por exemplo) evidenciam a meta brasileira de contribuir para o estabelecimento de um sistema internacional multipolar. Logo, de acordo com Vizentini (2005), o Brasil procura mais espaço para barganha e uma alternativa mais democrática ao domínio do mundo desenvolvido, nas relações internacionais.

A integração regional e a diversificação de parcerias globais parecem estar alinhadas à hipótese deste trabalho. Para alcançar o comando do Atlântico Sul, o Brasil teria de engajar-se com regiões que não ocidentais, especialmente na África, e participar de instituições que limitem o envolvimento ocidental. A próxima seção descreverá acontecimentos recentes, nas relações multilaterais e bilaterais, a respeito do Atlântico Sul.

\section{RELAÇÕES SUL-ATLÂNTICAS}

\subsection{Relações multilaterais}

Há quatro estruturas multilaterais para as relações do Brasil com países do Atlântico Sul: o Tratado Interamericano de

6 Brasil, Rússia, Índia, China e África do Sul. 
Bruno Gomes Guimarães

Assistência Recíproca (TIAR), a Zona de Paz e Cooperação do Atlântico Sul (ZOPACAS), a Comunidade dos Países de Língua Portuguesa (CPLP) e o Conselho de Defesa Sul-Americano (CDS). Enquanto o primeiro já perdeu sua importância e a preocupação do último não é o Atlântico Sul em si, a ZOPACAS e a CPLP emergiram como importantes fóruns para cooperação em temas relacionais ao oceano.

O TIAR foi elaborado entre 1936 e 1947 , sob o espectro da $2^{a}$ Guerra Mundial e da Guerra Fria. ${ }^{7}$ Ele baseava-se na solidariedade continental e assistência recíproca contra agressões externas e internas. Todavia, nunca houve forças armadas regulares dedicadas ao TIAR nem uma institucionalização do tratado. Ele é, antes, uma aliança militar defensiva que não possui os meios para assegurar sua implementação. Isso significa que os países não podem realmente ajudar-se em caso de ataques (CASTRO, 2002).

O tratado foi invocado somente três vezes, desde sua criação: durante a crise dos mísseis de Cuba, após os ataques terroristas de 11 de setembro de 2001 e durante a Guerra das Malvinas. Este foi o evento mais significativo. Para a maioria dos países latino-americanos, o fato de os EUA não terem apoiado a Argentina em sua guerra contra o Reino Unido efetivamente demonstrou que o TIAR era um instrumento datado e desprovido de qualquer valor geopolítico (CASTRO, 1997; 2002). Isso mostrou que a região não poderia contar com os EUA para se protegerem de ataques externos. O México foi o primeiro país a oficialmente desobrigar-se do tratado, pouco antes da invasão dos EUA ao Iraque, em 2003. ${ }^{8}$ Desde então, Nicarágua, Venezuela, Bolívia e Equador fizeram o mesmo, mostrando um claro descontentamento regional com a política externa estadunidense.

7 Os EUA eram seu principal patrocinador, temendo a crescente influência da Alemanha nazista e da União Soviética na América Latina. Sua característica principal é a defesa coletiva contra intervenções de potências estrangeiras nas Américas. O TIAR era visto como a materialização da Doutrina Monroe ("América para os americanos").

8 Cuba já havia denunciado o tratado em 1960, após a revolução e com o rompimento de relações diplomáticas com os EUA. 
Embora o Brasil ainda seja parte do TIAR, há uma tentativa de diminuir a sua importância. Especialmente após a criação do CDS, o Brasil percebe que a segurança da América do Sul é de responsabilidade primária dos próprios países sul-americanos, sem influência direta dos EUA (PAGLIARI, 2015).

Entretanto, O CDS não tem conteúdo extrarregional. Possivelmente, para o Brasil, ele é a principal estrutura para lidar com temas securitários, desde a sua criação, em 2008, mas seu escopo está limitado à própria América do Sul. Temas sul-atlânticos são tangenciais à agenda do CDS. Ainda assim, o órgão condenou a ocupação britânica nas Malvinas e proibiu que navios de bandeira das ilhas Falkland atraquem em portos sul-americanos (GOMES GUIMARÃES, 2015a; 2015b).

A principal estrutura multilateral empregada pelo Brasil para assuntos relacionados ao Atlântico Sul é a ZOPACAS. Nos anos 2000, o fórum foi revitalizado por ação angolana que contou com apoio brasileiro. ${ }^{9}$ Foi lançado em 1986, mediante forte iniciativa nigeriana e brasileira, que queriam limitar a influência das antigas potências coloniais no Atlântico Sul e distanciá-lo da divisão Leste-Oeste da Guerra Fria. Portanto, a criação da ZOPACAS visava a evitar a presença de armas de destruição em massa na região, bem como a presença de potências extrarregionais no oceano (semelhante a uma "Doutrina Monroe para o Atlântico Sul"). Entretanto, seu revigoramento, nos anos 2000, focou-se em cooperação econômica; em combate a atividades ilícitas e ao crime organizado; e em operações de paz e pesquisa científica (ambiental e marítima). Porém, pela primeira vez, os Estados-membros da ZOPACAS apelaram ao Reino Unido, para que findasse sua ocupação das Malvinas.

Em 2013, o Brasil também propôs maior aprofundamento das relações entre os países da ZOPACAS, incluindo, em temas

9 Sua criação contou com o apoio de três países sul-americanos e 21 africanos. A Assembleia Geral da ONU reconheceu a ZOPACAS de modo quase unânime, em 1986. Apenas os EUA votaram contra, com abstenções de Alemanha, França, Portugal, Itália e algumas outras antigas potências coloniais. Muitos analistas pensavam que, com o fim da Guerra Fria, a ZOPACAS perdera sua razão de ser. 
Bruno Gomes Guimarães

securitários. O ministro da Defesa, Celso Amorim, ofereceu o compartilhamento de know-how para o mapeamento de plataformas continentais, fortalecimento de capacidades para operações de resgate no mar, operações de paz e monitoramento marítimo, através de rastreamento e identificação de longo alcance (BRASIL, 2013). Além disso, o Brasil também sugeriu a criação de seminários da ZOPACAS, para tratar da defesa do Atlântico Sul.

Analogamente, no mesmo período, o Brasil defendeu dentro da CPLP uma iniciativa abrangente para o mapeamento de plataformas continentais. Havia dois objetivos concretos: a criação de um Atlas dos Oceanos da CPLP e a extensão das plataformas continentais dos seus Estados-membros (particularmente na África). Em matéria securitária, o Brasil sediou a Operação Felino. Essa foi uma série de exercícios militares na costa brasileira dentro do arcabouço institucional da CPLP, para treinar as Forças Armadas dos Estados-membros, para operações de paz. Em outras palavras, o Brasil queria criar uma "mentalidade marítima" dentro da organização. Conquanto haja membros de todos os continentes na organização, as iniciativas foram voltadas para o Atlântico Sul (ABDENUR; SOUZA NETO, 2014).

O comportamento brasileiro, em instituições multilaterais, a respeito do Atlântico Sul parece corroborar a hipótese do trabalho. Por um lado, o Brasil tentou distanciar-se de estruturas que incluem os EUA. Evitar a principal potência extrarregional do oceano sugere que Brasília está perseguindo uma maior autonomia na região. Mesmo que as políticas brasileiras não apontem inequivocamente para a busca do comando do mar, elas evidenciam a disposição do Brasil de, ao menos, limitar a influência extrarregional no Atlântico Sul. Ademais, Brasília tentou aumentar as capacidades estatais dos seus parceiros africanos, conscientizando-os de temáticas sul-atlânticas, através da ZOPACAS e da CPLP. Em ambos os lados do oceano, o Brasil visou ao fortalecimento da identidade sul-atlântica, enfatizando necessidades e preocupações em comum - especialmente concernentes a recursos marítimos (ABDENUR; SOUZA NETO, 2014). 


\subsection{América do Sul}

Na América do Sul, a Argentina é o país que mais tem temas securitários relacionados ao Atlântico Sul. Ela possui reivindicações territoriais sobre diversas ilhas sul-atlânticas que se encontram sob domínio britânico, nomeadamente as Malvinas e as ilhas Sandwich do Sul e Geórgia do Sul. Todas fazem parte dos trampolins insulares identificados por Castro (2002).

Desde a Guerra das Malvinas, nos anos 1980, a Marinha argentina está gravemente debilitada (PETERSEN, 2012). O país tem a ambição de fortalecê-la e modernizá-la, mas não encontra sucesso, devido a restrições orçamentárias. Atualmente, a Armada Argentina possui 19.000 soldados, mais 7.200 funcionários civis e 2.500 fuzileiros navais. Ela conta com três submarinos táticos, cinco destróieres, seis fragatas, 17 barcos de patrulha, 18 belonaves anfíbias e 26 navios de apoio logístico (IISS, 2016).

As relações brasileiras com a Argentina passaram por uma transformação notável, ao final do século XX, indo da rivalidade continental à estreita cooperação: ambos são considerados o motor propulsor da integração sul-americana. No escopo da UNASUL e do CDS, o Brasil tem apoiado as reivindicações argentinas sobre as Malvinas.

A respeito do Atlântico Sul, Brasil e Argentina realizaram muitos exercícios militares navais conjuntos. Bilateralmente já ocorreram seis, desde 2000, sob o nome de Operação Araex. Houve outros com a participação do Uruguai, tais como o Transamérica, Temperex e Atlasur, este também incluindo a África do Sul. Todos eles visam ao fortalecimento da confiança entre os envolvidos. Seus cenários simulados incluem a proteção de rotas marítimas e o estancamento de invasões (VAZ, 2011). Também ocorreram os exercícios chamados de Operação Fraterno, os quais simulam operações anfíbias, envolvendo os exércitos e as marinhas de ambos os países. Em algumas ocasiões, a África do Sul foi convidada a participar deles.

As relações do Brasil com o Uruguai têm sido cooperativas, desde o início do século XX, quando o Brasil cedeu territórios costeiros aos uruguaios de maneira unilateral. ${ }^{10}$ Porque é um país

10 Para uma discussão mais ampla, ver Gomes Guimarães, Sebben e Duarte (2011). 
Bruno Gomes Guimarães

pequeno, a Marinha uruguaia reflete essa característica. Ela conta com 5.400 soldados, incluindo a guarda costeira. Também há uma infantaria naval de 450 soldados. O Uruguai possui 33 vasos: duas fragatas, 15 barcos de patrulha, três navios caça-minas, três navios anfíbios e 10 de apoio e logística (IISS, 2016).

O Brasil também realizou diversos exercícios militares navais com o país. Neles, as marinhas simulavam cenários em que elas tinham de manter as rotas marítimas livres de interferência externa no Atlântico Sul. Também é simulado o combate a atividades ilegais em suas águas territoriais, tais como tráfico de drogas. Esses exercícios bilaterais são chamados de Uruex. Como mencionado anteriormente, o Uruguai também tem participado de exercícios militares multilaterais, como o Transamérica, Temperex e Atlasur.

\section{3 África subsaariana}

\subsubsection{Nigéria}

Desde a sua independência, a Nigéria tem sido a principal parceira do Brasil na África. Atualmente, os laços que os unem abarcam comércio, cultura e política entre outros. Em 2013, as relações bilaterais atingiram o status de parceria estratégica. O apoio brasileiro ao papel político desempenhado pela Nigéria, na África Ocidental, através da Comunidade Econômica de Estados da África Ocidental (CEDEAO), e no continente africano como um todo, ilustra o fato.

A Nigéria tem a marinha mais poderosa da África Ocidental, com 8.000 soldados, incluindo a guarda costeira. O país possui uma fragata, uma corveta, 114 barcos de patrulha, cinco vasos anfíbios, 10 navios de logística e apoio e 2 para guerra antimina (IISS, 2016). Entretanto, conforme o Military Balance 2013, muito do seu equipamento está impróprio para mobilizações longas, devido à deterioração (IISS, 2013). Os principais desafios enfrentados pela Marinha da Nigéria são militantes no Delta do Níger e a pirataria no Golfo da Guiné. Por causa disso, muitas de suas aquisições são voltadas para navios de patrulha costeira e de alto-mar. 
O ano de 2010 foi marcante nas relações Brasil-Nigéria. Foi quando a primeira reunião de cúpula Brasil-CEDEAO aconte$\mathrm{ceu}$, na qual Brasília apoiou a liderança nigeriana novamente (cf. BRASIL, 2010), e um acordo militar bilateral foi negociado. Nele, o Brasil se comprometeu a treinar oficiais da Marinha nigeriana e a fornecer vasos de guerra. Esses programas se mantêm desde então.

\subsection{2 África do Sul}

A localização da África do Sul é assaz estratégica, dada a conexão entre o Índico e o Atlântico. Hoje, aproximadamente 60\% do petróleo vindo do Oriente Médio para a Europa e América do Norte passa pelas águas sul-africanas (FIORI; PADULA; VATER, 2012).

Embora sua marinha historicamente tenha estado sob tutela britânica (PENHA, 2011), uma segurança marítima independente é uma preocupação crescente para a África do Sul, devido à pirataria no Índico. Possuindo 7.650 soldados, a Marinha sul-africana é composta de três submarinos táticos, quatro fragatas, seis vasos de patrulha, seis belonaves anfíbias, oito navios logísticos e dois antiminas (IISS, 2016). Se estivesse concentrada no Atlântico Sul, ela seria a marinha africana mais forte no oceano, porém, o país tem de dividir suas forças entre o Atlântico e o Índico. Isso faz com que o peso da Marinha sulafricana seja menor do que o desejável (KORNEGAY, 2013; IISS, 2013).

A África do Sul tornou-se uma das principais parceiras políticas do Brasil, alcançando o grau de parceria estratégica, em 2010. ${ }^{11}$ Através de iniciativa brasileira, o país foi incluído nos BRICS. Ademais, criou-se um fórum entre os dois países mais a Índia, nos anos 2000, o IBAS. Nessas instituições, o Brasil demonstrou apoio ao papel sul-africano em assuntos securitários do sul da África (VAZ, 2011).

11 O Brasil mantinha relações diplomáticas bem limitadas com a África do Sul durante o Apartheid. Por um lado, havia um desejo de cooperar em temas securitários, mas, por outro, o país queria aprofundar seus laços com os demais países subsaarianos (e, para isso, as relações com Pretoria eram um entrave). Com o fim do Apartheid, as relações bilaterais deslancharam (PEREIRA, 2010). 
Bruno Gomes Guimarẽes

Um acordo de cooperação militar foi assinado entre os dois países, em 2003. As marinhas brasileira e sul-africana trabalham em estreita cooperação para assegurar a proteção de fronteiras marítimas, bem como o acesso a rotas sul-atlânticas (KORNEGAY, 2013). Também há exercícios militares conjuntos, nomeadamente Atlasur (contando também com Argentina e Uruguai), IBSAMAR (com a Índia) e Fraterno (com a Argentina também). Brasil e África do Sul também trabalharam conjuntamente para desenvolver os mísseis ar-ar de quinta geração A-Darter, que devem ser adaptados para uso nos caças Gripen NG brasileiros. ${ }^{12}$ Ambos os países também estão negociando o desenvolvimento conjunto de aeronaves militares de carga, mísseis terra-ar e veículos aéreos não tripulados (drones) (VAZ, 2011; KORNEGAY, 2013).

\subsubsection{Angola}

Angola é um dos principais parceiros do Brasil na África, não apenas por sua história compartilhada, mas também porque as relações bilaterais têm sido intensas, desde 2000, tornando-se estratégicas, em 2010.13 O petróleo foi uma das principais razões para a retomada dos laços, nos anos 1970, quando o Brasil estava em busca de fontes alternativas, no contexto da crise do petróleo. Atualmente, a Petrobrás se faz presente em Angola, na prospecção de petróleo em alta profundidade. Uma miríade de outras empresas brasileiras também está presente no mercado angolano, para não mencionar intercâmbios acadêmicos e culturais.

12 Em dezembro de 2013, o Brasil anunciou a aquisição dos caças suecos de 4,5 geração Gripen NG. Suécia e Brasil desenvolverão conjuntamente os aviões, incluindo adaptações para navios-aeródromo (ver OLIVEIRA et al., 2013).

13 Sob colonização portuguesa, o comércio entre os dois países era maior do que o de cada um deles com Portugal (PENHA, 2011). Com efeito, quando o Brasil tornou-se independente, havia um forte movimento político em Angola, a favor de juntar o país ao Império brasileiro, em vez de permanecer sob domínio português (PENHA, 2011). Contudo, após o rompimento dos laços, devido ao fim do tráfico negreiro e da ascensão comercial britânica, as relações bilaterais ficaram praticamente não existentes. A reaproximação veio a ocorrer nos anos 1970, com o processo de descolonização em Angola. Apesar de existir uma ditadura militar de direita no Brasil e um governo comunista, em Angola, o Brasil foi o primeiro país a reconhecer a independência angolana. As relações bilaterais deslancharam e tornaram-se prioritárias para Brasília desde então. 
Brasil e Angola são bastante próximos, em assuntos sul-atlânticos. Os intercâmbios entre suas marinhas foram aumentados, desde 2000. A Marinha de Angola tem aproximadamente 1.000 combatentes e 22 barcos patrulheiros (IISS, 2016). Apesar de seu tamanho, ela é regionalmente significativa (IISS, 2013). ${ }^{14}$ O Brasil também iniciou o mapeamento da plataforma continental angolana. Esse programa, chamado de Plano de Levantamento da Plataforma Continental Angolana (LEPLACA), é uma iniciativa bilateral, sob a égide da ZOPACAS. Na CPLP, o Brasil também é responsável pela seção de Angola no Atlas dos Oceanos. Ambos conduzem pesquisa conjunta, nos ramos de construção de navios (de carga), defesa e segurança pública (FIORI; PADULA; VATER, 2012), porém a queda nos preços do petróleo interrompeu negociações para a compra de navios patrulheiros brasileiros (IISS, 2016).

\subsubsection{Namíbia}

Desde a independência namibiana, o Brasil cooperou com o país especialmente, no que diz respeito à proteção do oceano. Com efeito, a Marinha do Brasil é a principal responsável pela criação da Marinha namibiana. Presentemente, ela tem cerca de 200 combatentes, para oito barcos de patrulha e cinco de apoio logístico (IISS, 2016). Diminuta, a Marinha namibiana faz parte do Ministério da Pesca.

Programas foram estabelecidos bilateralmente pelo Brasil com a Namíbia, para o treinamento de oficiais de marinha e marinheiros, desde o início dos anos 1990. Eles foram aprofundados, nos anos 2000, através do Acordo de Cooperação Naval (ACN). No escopo deste, o Brasil ajudou a criar e treinar os Fuzileiros Navais Namibianos, além de assistir o estabelecimento do Serviço de Patrulha Marítima da Namíbia. Até hoje, centenas de namibianos se formaram na Escola de Guerra Naval brasileira.

Sob o ACN, o Brasil também mapeou a plataforma continental da Namíbia, tendo terminado, em 2007. Também foram doados

14 Isso é especialmente verdadeiro no contexto do Golfo da Guiné. 
Bruno Gomes Guimarães

vários navios de guerra e barcos de patrulha, ressaltando-se a Corveta Purus, em 2004, que saiu de serviço em 2012. Ademais, o Brasil tem uma missão naval permanente em Walvis Bay, um dos melhores portos naturais do sudoeste africano. ${ }^{15}$

\subsubsection{Outros}

O Brasil também aumentou sua influência, em outros países africanos sul-atlânticos, desde 2000. A Petrobrás possui plataformas de petróleo no Gabão e no Congo-Brazzaville. Com a GuinéBissau, o Brasil possui um acordo militar que ajudou a constituir as primeiras Forças de Segurança do país, através da Missão Brasileira de Cooperação Técnico-Militar (FIORI; PADULA; VATER, 2012). Navios de guerra, patrulheiros e uniformes navais foram doados para o país. O mesmo gesto foi estendido para São Tomé e Príncipe. ${ }^{16}$ Tanto este quanto Guiné-Bissau fazem parte da iniciativa de mapeamento da plataforma continental da CPLP. O Brasil, inclusive, abriu uma embaixada em São Tomé, em 2003, por motivos estratégicos: o arquipélago é central para o Golfo da Guiné (AMORIM, 2013). Por fim, o Brasil também vendeu uma corveta para Guiné Equatorial, em um acordo que incluía o treinamento de oficiais e soldados. Instrutores navais da Marinha do Brasil também foram enviados para Benim. Um acordo militar foi assinado com Senegal. Mais recentemente, em 2013, o Brasil inaugurou uma missão naval permanente no Cabo Verde, para assistir o treinamento de guardas costeiros.

\subsection{Estados Unidos}

O Brasil tem sido cuidadoso com a presença estadunidense, no Atlântico Sul. Tem sido assim, especialmente, após o apoio dos EUA à tentativa de golpe na Venezuela, em 2002, e o rápido

15 Essa missão naval permanente não é o mesmo que uma base militar. Não há navios de guerra, apenas poucos enviados militares são enviados para o treinamento regular de soldados da marinha namibiana.

16 Vale notar que a doação de belonaves a esses países africanos também fez aumentar a demanda junto à indústria militar brasileira. 
reconhecimento do governo paraguaio após o golpe parlamentar de 2012. Esses eventos resultaram em um menor envolvimento político dos EUA na região, mas também significaram uma maior presença militar do país no continente sul-americano (BANDEIRA, 2008). ${ }^{17}$

A Marinha dos EUA, tradicionalmente, divide suas forças igualmente entre o Atlântico e o Pacífico. Contudo, ela já começou a alterar esse equilíbrio em prol do Pacífico, para alcançar uma divisão de razão 40/60. Atualmente, ela possui 326.800 soldados (IISS, 2016). Os EUA têm 71 submarinos, 14 dos quais armados com ogivas nucleares, 10 navios-aeródromo, 22 cruzadores, 62 destróieres, quatro fragatas, 57 patrulheiros, 11 antiminas, dois navios de comando e 275 anfíbios, além de 71 vasos para logística e apoio (IISS, 2016). Os EUA também possuem uma frota inativa, composta por um navio aeródromo, um vaso de apoio e 12 anfíbios, que pode ser reativada mediante aviso prévio de 60 a 90 dias (IISS, 2016). O Comando de Guerra Especial da Marinha tem 9.850 combatentes, de acordo com o IISS (2016), e o Comando de Operações Especiais Marinhas, 3.000 combatentes. Além disso, o país também tem um Comando Militar de Transporte Marítimo, o qual conta com 150 navios de logística e apoio. A Guarda Costeira dos EUA é composta por 40.000 funcionários militares e 8.300 civis (IISS, 2016). Ela possui 163 barcos de patrulha e 394 navios de logística e apoio (IISS, 2016).

Os EUA estão militarmente presentes no Atlântico Sul, na ilha britânica de Ascensão - componente de um dos trampolins insulares identificados por Castro (2002) -, onde contam com um radar de deteç̧ão e rastreamento. Também se fazem presentes, através da $4^{a}$ Frota que foi reativada em 2008, logo após a descoberta do Pré-Sal. Os motivos apresentados pelos EUA para sua reativação foram o combate ao tráfico ilegal e o fortalecimento da segurança

17 Ademais, a publicação de documentos secretos dos EUA sobre o golpe militar brasileiro, em 1964, mostrou que o país teve enorme influência sobre o evento e, inclusive, possuía planos militares para assegurar a vitória do golpe, caso fosse necessário (BANDEIRA, 2008). Esses planos incluíam uma grande operação naval no Atlântico Sul (chamada Big Brother) (BANDEIRA, 2008). Além disso, aos olhos do Brasil e de outros países latino-americanos, os EUA não cumpriram com sua obrigação conforme o TIAR, durante a Guerra das Malvinas (CASTRO, 1997; 2002). 
Bruno Gomes Guimarães

regional (BANDEIRA, 2008). ${ }^{18}$ Os EUA também têm dois comandos militares para a região, o USSOUTHCOM, desde 1964 (para a América do Sul), e o AFRICOM, desde 2007 (para a África subsaariana). Há 250 soldados estadunidenses em serviço no Níger e 300 em Camarões (IISS, 2016). O país também contribui com algumas tropas para as operações de paz no Mali e na Libéria. ${ }^{19}$

Apesar da desconfiança, o Brasil frequentemente junta-se à Marinha dos EUA para a realização de exercícios militares com outros países sul-americanos, mas não regularmente. ${ }^{20}$ Navios de guerra dos EUA vêm amiúde a portos brasileiros para reabastecimento, desde os anos 2000, mesmo que não haja um acordo bilateral formal para isso (ALBUQUERQUE, 2010). Mais recentemente, o Brasil tem participado, desde 2012, anualmente nos exercícios militares navais Obangame Express, liderados pelos EUA, no Golfo da Guiné. Esses incluem operações antipirataria e de combate a outras atividades ilícitas no leste do Atlântico Sul. Inicialmente a participação brasileira era limitada a observadores militares, mas, desde 2014, navios patrulheiros têm sido enviados (COMANDO..., 2016; SOARES, 2015; ABDENUR; SOUZA NETO, 2014). Muitos países europeus e africanos participam também.

\subsection{Reino Unido}

O Brasil é bastante precavido quanto à presença do Reino Unido, no Atlântico Sul - afinal, o país controla a maioria das ilhas dos trampolins insulares identificados por Castro (2002). A história das relações entre ambos no século XIX mostra que o Brasil tem razão para ser cauteloso. ${ }^{21}$ Brasília apoiou a Argentina

18 È preciso ressaltar que a $4^{a}$ Frota não conta com nenhuma belonave permanentemente designada para si. Atualmente ela é apenas uma estrutura de comando e mobilizações acontecem apenas esporadicamente.

1910 soldados no Mali e quatro observadores militares na Libéria (IISS, 2016).

20 Todavia, há exercícios aéreos conjuntos duas vezes ao ano. Um deles é o Cruzex, tido como um dos maiores exercícios militares da América Latina.

21 O Reino Unido ameaçou bombardear portos brasileiros, fez um bloqueio no Rio de Janeiro e afundou muitos navios, o que ficou conhecido como Incidente Christie, culminando com o rompimento de laços diplomáticos entre ambos que perduraria por dez anos. Na verdade, o Brasil quase declarou guerra contra o Império Britânico àquela época. Além disso, dada a campanha naval britânica 
na Guerra das Malvinas e há um apoio oficial às reivindicações argentinas sobre as ilhas no Atlântico Sul de possessão britânica. Contudo, isso não teve maiores repercussões nas relações com Londres, inclusive, após a proibição de atracação a navios ostentando bandeira de Falkland, em portos sul-americanos, feita pelo CDS (FIORI; PADULA; VATER, 2012).

A Marinha Real Britânica tem 32.500 soldados em serviço. Ela possui 10 submarinos, quatro dos quais são armados com ogivas nucleares, seis destróieres, 13 fragatas, 22 patrulheiros, 16 navios antimina, três anfíbios e 10 para logística e apoio (IISS, 2016). Presentemente, a marinha britânica não tem navios-aeródromo, mas dois foram comissionados e devem ser entregues, entrando em operação até 2018.

O Reino Unido tem forças destacadas em todo o Atlântico Sul. A presença militar mais significativa está nas Malvinas, onde se encontram aproximadamente 1.100 soldados em serviço permanente (IISS, 2016). Também há tropas na Ilha de Ascensão, Mali e Serra Leoa, com cerca de 30 soldados em cada (IISS, 2016). Um destróier da Marinha Real também patrulha permanentemente o oceano (IISS, 2013).

As relações do Brasil com o Reino Unido vêm sendo cordiais, no século XXI. Assim sendo, o Brasil comissionou a construção de destróieres britânicos para sua marinha. Essas encomendas, porém, foram feitas sem muito planejamento: o Brasil as fez em situações de "liquidação", quando outros países cancelaram seus contratos com o Reino Unido (OLIVEIRA; CEPIK; BRITES, 2013). Interessantemente, as belonaves britânicas compradas por Brasília fizeram um tour por países africanos, antes de vir ao Brasil. Contudo, não houve exercícios militares conjuntos das marinhas britânica e brasileira, desde 2000.

contra o tráfico negreiro, os laços comerciais entre Brasil e África foram imensamente afetados. Com efeito, o golpe foi tão forte que o Brasil distanciouse completamente do continente, por quase um século após isso (PENHA, 2011). 
Bruno Gomes Guimarães

\subsection{França}

Similar ao Reino Unido, a França também atacou cidades litorâneas brasileiras no passado. Isso engendrou um comportamento bastante cauteloso do Brasil, que tem muitas suspeitas quanto às intenções francesas no Atlântico Sul. ${ }^{22}$ Isso é particularmente verdadeiro em relação ao intervencionismo francês, na África (OLIVEIRA et al., 2013).

Há presença militar francesa, em vários países do Atlântico Sul. Em 2016, os principais destacamentos são no Mali, Costa do Marfim, Gabão, Níger, Burkina Faso e Senegal, com aproximadamente 4.000 soldados divididos entre eles (IISS, 2016). Ademais, a França mantém um navio de assalto anfíbio em alerta, no Golfo da Guiné (IISS, 2016). A Marinha francesa conta com 38.250 soldados, incluindo 2.200 das Forças Nucleares Estratégicas (IISS, 2016). Possui quatro submarinos com ogivas nucleares, seis táticos, um navio-aeródromo, 11 destróieres, 11 fragatas, 20 patrulheiros, 18 navios antimina, 45 anfíbios e 145 para logística e apoio (IISS, 2016). Além disso, na Guiana Francesa - nos limites do Atlântico Sul -, a França tem cerca de 2.100 combatentes e, no Caribe, 1.000 (IISS, 2016).

Mesmo assim, apesar de toda cautela, o Brasil assinou um acordo militar estratégico com a França, em 2008, para a modernização de sua marinha. A França construiria com o Brasil cinco submarinos, um movido à energia nuclear (reator de tecnologia brasileira) e quatro convencionais. O papel francês seria o desenho e construção das partes não nucleares, principalmente o casco (IISS, 2013). Todos os submarinos devem ser feitos no Brasil, ou seja, é um acordo que inclui transferência de tecnologia. O primeiro deve ser entregue em 2023. Além disso, a França auxiliou o Brasil no mapeamento de seu leito marinho. Ambos trabalharam

22 O incidente mais recente que quase levou à guerra aberta entre ambos foi a chamada "Guerra da Lagosta", nos anos 1960. À época, a França repetidamente violava as águas jurisdicionais brasileiras para a captura de lagostas, apesar de diversos alertas de Brasília. França e Brasil chegaram até mesmo a deslocar navios de guerra para a porção norte do Atlântico Sul (no nordeste brasileiro), mas ambos concordaram em dissipar as tensões e aceitaram mediação internacional, para a resolução da disputa, a qual terminou em favor do Brasil (RAFFAELLI, 2003; LESSA, 1999; CARVALHO, 1999). 
juntos também em operações de resgate, no Atlântico Sul, na região entre Brasil e Senegal/Cabo Verde.

\section{O ATLÂNTICO SUL NA ESTRATÉGIA BRASILEIRA}

\subsection{Políticas domésticas}

Em 2004, a Marinha do Brasil lançou o conceito de "Amazônia Azul", um pleito junto à ONU para a extensão da plataforma continental do país. O Mapa 2 apresenta a área que seria adicionada ao território brasileiro. Caso seja completamente aceito pela Comissão de Limites da Plataforma Continental (CLPC), o território brasileiro aumentaria em 50\%. Em 2007, a CLPC validou 81\% do pleito. Para os $19 \%$ restantes, o Brasil apresentou novas propostas, as quais estão sendo analisadas pela CPLC (PEREIRA DA SILVA, 2013).

Desde os anos 2000, o Brasil adotou diversas políticas, para levantamento e proteção da Amazônia Azul e para garantir sua presença no Atlântico Sul. Foram desenvolvidos dois programas para lidar com recursos marítimos, o PROAREA e o Biomar, que tratam da prospecção e exploração de recursos minerais e vivos no Atlântico Sul, respectivamente. Relacionado a eles, o Plano de Levantamento da Plataforma Continental Brasileira foi implementado. Estudos do PROAREA também levaram a uma autorização da ONU, para explorar minerais da Elevação do Rio Grande, no alto-mar do Atlântico Sul, em 2014.23

Em questões de pesquisa científica no Atlântico Sul, o Brasil adotou dois programas: Protrindade e Proantar. O primeiro objetiva o desenvolvimento do arquipélago de Trindade, parte de um dos trampolins insulares. O segundo inclui iniciativas que envolvem a pesquisa sobre a Antártida, levantamento e exploração das águas geladas, próximas ao Atlântico Sul. O programa Proarquipélago, semelhante a eles, é uma política para a pesquisa em todas as ilhas sul-atlânticas brasileiras. Implementado pela Marinha do Brasil, seu objetivo principal é garantir que todas as ilhas sejam permanentemente habitadas. Assim, o Brasil assegura uma ZEE maior no Atlântico Sul.

23 Para mais informações sobre a Elevação do Rio Grande, ver Aquino et alli (2016). 
Bruno Gomes Guimarães

Mapa 1: A Amazônia Azul

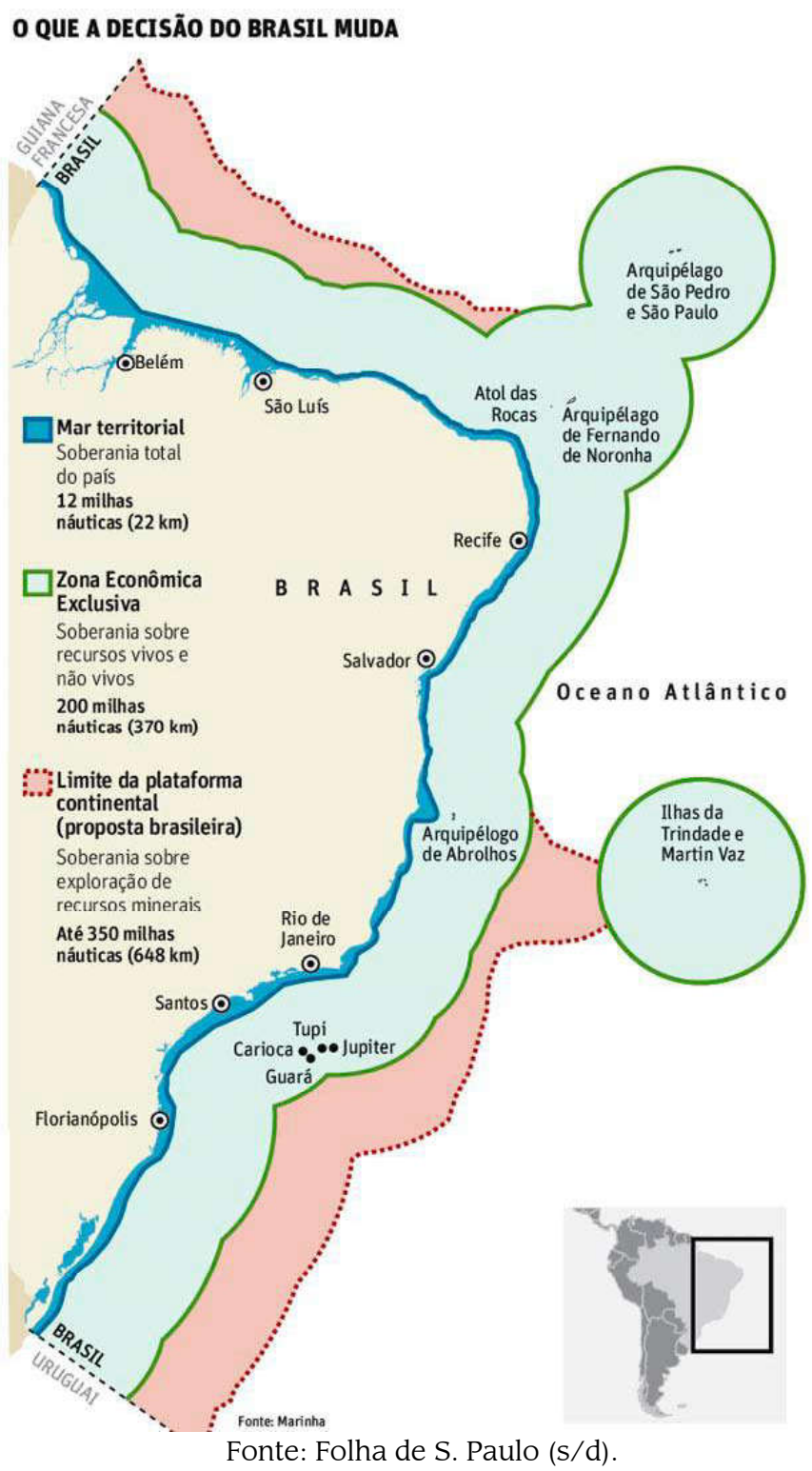

282 | Tensões Mundiais, Fortaleza, v. 12, N. 22, P. 259-293, 2016 
O Brasil também começou a desenvolver o Sistema de Gerenciamento da Amazônia Azul (SisGAAz). Ele seria usado para fins civis e militares, pois inclui um sistema de monitoramento bastante ambicioso. Todas as tecnologias usadas pelo SisGAAz estão sendo desenhadas por empresas brasileiras. Entretanto, embora ele deva entrar em operação total em 2027, o programa foi suspenso indefinidamente devido a restrições orçamentárias (STOCHERO, 2015). Também há especulações de que empresas estrangeiras poderiam se juntar a ele (SANTAYANA, 2015).

5.2 Capacidades militares atuais e programas de aquisição

O Livro Branco de Defesa Nacional e a Política Nacional de Defesa do Brasil $(2005 ; 2012)$ declaram que o Atlântico Sul é estratégico para a segurança do país. A negação do comando do oceano para potências estrangeiras é um de seus principais objetivos e tem orientado o desenvolvimento da marinha desde, pelo menos, 2005.

O Brasil tem 69.000 soldados em serviço na sua marinha. O país possui cinco submarinos táticos, um navio-aeródromo, três destróieres, 10 fragatas, 48 vasos de patrulha, cinco navios antiminas, 38 anfíbios e mais de 100 naves para logística e apoio (IISS, 2016). Apesar de ser a maior e mais poderosa marinha dos países sul-atlânticos, ela ainda é insuficiente em comparação com as potências extrarregionais (França, Reino Unido e EUA). Por consequência, o Brasil não se sente ameaçado por seus vizinhos, mas é bastante apreensivo quanto à interferência de "potências de fora da região" (IISS, 2013; ALBRECHT, 2011). Há um medo de invasão da Amazônia Verde e Azul. O ex-ministro da Defesa e das Relações Exteriores, Celso Amorim, deu exemplos de possíveis ameaças ao Brasil, as quais incluíam somente cenários envolvendo o Atlântico Sul. Amorim (2013) menciona especificamente a capacidade de explorar reservas de petróleo ultraprofundas e rotas marítimas, como sendo as principais vulnerabilidades brasileiras, no oceano.

Mesmo sendo a quarta maior marinha dentre os países considerados neste artigo, como pode ser visto na Tabela 1, a maioria 
Bruno Gomes Guimarães

das belonaves e equipamentos brasileiros precisam ser substituídos e modernizados (BRITES; MARTINS; SILVA, 2013). Esse tem sido um objetivo permanente do Brasil, desde 2000. A marinha realizou investimentos no Programa de Desenvolvimento de Submarinos (PROSUB) e no Plano de Articulação e Equipamento da Marinha Brasileira (PAEMB) para a obtenção de submarinos nucleares. Enquanto a tecnologia nuclear será 100\% brasileira, a França deve transferir tecnologia para o desenvolvimento completo do submarino. Conforme a Estratégia de Defesa Nacional (EDN), o país deve construir 15 submarinos convencionais, mais seis nucleares (BRASIL, 2005). Não há prazo oficial, mas os primeiros devem se tornar operacionais, em 2023.

A Marinha do Brasil também pretende renovar sua frota de superfície. Um dos principais programas com esse fim é o PROSUPER, que prevê a construção, em solo nacional, de cinco fragatas, cinco patrulheiros e um vaso de apoio logístico. Diversos países europeus e do leste asiático já demonstraram interesse em desenvolver parcerias com o Brasil para isso (OLIVEIRA; CEPIK; BRITES, 2013). Mesmo assim, restrições orçamentárias afetaram a maioria desses programas de modernização e aquisição de capacidades, incluindo o próprio PROSUPER, suspenso em 2011. O PROSUB é o único programa que não padece significativamente desses problemas. A construção de submarinos convencionais e nucleares manteve-se, apesar das dificuldades econômicas, enquanto a construção e a aquisição de outros vasos foi interrompida (ALBRECHT, 2011; IISS, 2013) ${ }^{24}$ Contudo, medidas de austeridade fiscal recentes podem causar um atraso de quatro anos ao PROSUB (STOCHERO, 2015).

24 Ver os trabalhos de Martins Filho $(2011 ; 2014)$, para mais informações sobre o desenvolvimento do PROSUB através do tempo. 
Tabela 1: Marinhas sul-atlânticas

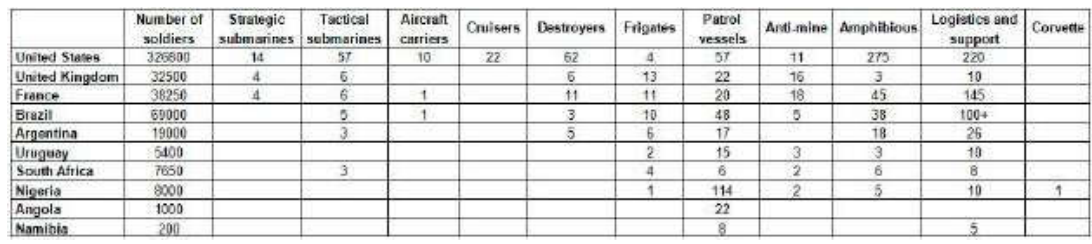

Fonte: elaboração própria com base nos dados do IISS (2016)

A Estratégia de Defesa do Brasil nota que submarinos, especialmente os nucleares, são essenciais para capacidades de negação de uso do mar (BRASIL, 2005; 2012). Assim, o país quer ter uma postura proativa na defesa da Amazônia Azul. Para fomentar pesquisas e iniciativas, em áreas relacionadas ao PROSUB, criou-se a empresa estatal de defesa Amazônia Azul Tecnologias de Defesa / Amazul, em 2012. Ela entrou em funcionamento em agosto de 2013 e tem provido assistência à construção de submarinos e outros vasos de guerra para a Marinha brasileira. A Amazul é vista como um meio de fazer avançar o PROSUPER, mas seus primeiros resultados podem vir somente em 2026.

Juntos, PROSUB, PROSUPER e SisGAAz podem dar ao Brasil capacidade de projeção de força consistente com a condição de potência global, mas atrasos em sua implementação tornam tudo incerto (IISS, 2013). Ao fim e ao cabo, a modernização da marinha:

$$
\begin{aligned}
& \text { [...] depende da condição da economia } \\
& \text { geral e em o quão necessário o Brasil acha } \\
& \text { que equipamentos militares de ponta são } \\
& \text { para sustentar suas ambições políticas } \\
& \text { internacionais. A ausência de uma ameaça } \\
& \text { estratégica convencional na região e, mais } \\
& \text { recentemente, o crescimento econômico } \\
& \text { lento contribuem para a relutância em tornar } \\
& \text { uma prioridade os gastos em defesa (IISS, } \\
& \text { 2013, p. 429, [tradução própria]). }
\end{aligned}
$$

Com efeito, a crise econômica que atingiu o Brasil em 2014 impactou severamente os projetos estratégicos da Marinha. O SisGAAz foi suspenso e o PROSUB pode sofrer um atraso de até quatro anos. O PROSUPER permanece inativo. Medidas de austeridade tomadas pela ex-presidente Dilma Rousseff, em 2015, 
Bruno Gomes Guimarães

e pelo governo de Michel Temer, em 2016, comprometem sua execução. Todavia, ainda continuam sendo projetos prioritários dentro da Marinha. Resta ver se a crise política atual os impactará negativamente a longo prazo.

5.3 Análise da estratégia geopolítica do Brasil para o Atlântico Sul

Considerando-se as relações sul-atlânticas do Brasil, a estratégia geopolítica do país, desde 2000, parece ter um cunho defensivo (e.g. BOHOU, 2007). No âmbito multilateral, o Brasil estimula a ZOPACAS, um agrupamento que não inclui potências extrarregionais. Bilateralmente, o país também tentou capacitar e fomentar o desenvolvimento dos países do Atlântico Sul. Certamente não são relações sem interesse, afinal, muito da cooperação bilateral também estimula o próprio desenvolvimento econômico brasileiro. Entretanto, iniciativas brasileiras visam à estabilidade no Atlântico Sul. Levando em conta que praticamente todo o comércio exterior do Brasil passa por rotas marítimas sul-atlânticas, a instabilidade no oceano é indesejável.

Historicamente o Brasil sofreu ameaças e mesmo agressão das potências extrarregionais consideradas nesta pesquisa: EUA, França e Reino Unido. Isso compreensivelmente criou certas suspeitas em Brasília. Mesmo assim, essa preocupação não impediu um engajamento cordial com elas. O Brasil participa de exercícios militares com os EUA e comprou vasos de guerra do Reino Unido. A parceria com a França é mais profunda do que com ambos, porque inclui assistência na construção de submarinos e um alto nível de transferência tecnológica. Isso é um sinal claro de que a posição brasileira não vai de encontro a esses países, apesar da história turbulenta.

Entretanto, é exatamente por causa desse passado que o Brasil tem procurado aumentar as capacidades de sua Marinha, as quais são marcadamente inferiores às francesas, britânicas e estadunidenses. PROSUB, PROSUPER e SisGAAz são exemplos claros de uma aspiração de modernizá-la. Porém, as políticas brasileiras civis e militares para o Atlântico Sul não indicam uma 
vontade de obter o comando geral do oceano. Programas de mapeamento, pesquisa e desenvolvimento, junto com a aquisição de submarinos e a implementação de sistemas de monitoramento, apontam para o fato de que o Brasil vem tentando garantir um comando local permanente de suas águas jurisdicionais. Isso significa que o Brasil quer assegurar que nenhum país possa interferir em suas atividades civis ou militares no mar.

Ademais, o Brasil tentou capacitar países africanos, mas sem procurar estabelecer bases navais na costa africana. O Brasil, de fato, possui missões navais permanentes na Namíbia e no Cabo Verde, mas elas estão longe de ser bases militares da Marinha brasileira, levando-se em conta que há poucos adidos militares e nenhuma belonave. Isso aponta para a conclusão de que o Brasil procura empoderar esses países africanos para torná-los capazes de lidar com instabilidades internas, sem a ajuda de potências extrarregionais, cuja presença intervencionista no continente suscita preocupações. Reveladoramente, em 2010, Portugal propôs a extensão do escopo da OTAN para o Atlântico Sul e o Ministro da Defesa do Brasil criticou, afirmando que tal medida não seria bem-vinda e seria prejudicial para a região. ${ }^{25}$

Essa estratégia, porém, não significa que o Brasil desafie o status quo no Atlântico Sul. O Reino Unido possui a maioria das ilhas dos trampolins insulares e os EUA, a frota mais poderosa. O Brasil não procura disputar seu comando geral sobre o Atlântico Sul. Certamente, o Brasil quer negar-lhes o comando sobre as suas próprias águas jurisdicionais, mas o predomínio deles sobre as rotas internacionais de comércio permanece inconteste. A única exceção é a questão das Malvinas/Falkland, na qual o Brasil apoia as reivindicações argentinas, mas, mesmo assim, bastante timidamente.

25 Isso remonta ao projeto de estabelecimento de uma aliança militar equivalente à OTAN no Atlântico Sul, a Organização do Tratado do Atlântico Sul (OTAS). Ele foi rejeitado pelo Brasil e pela Nigéria, nos anos 1980. 
Bruno Gomes Guimarães

\section{CONCLUSÃO}

O Brasil tem uma clara vocação marítima. O país tem condições geográficas favoráveis para lidar com o oceano e, no século XXI, houve vontade política para usufruir disso, através de muitas políticas. A integração regional da América do Sul fomenta desenvolvimento, paz e estabilidade. Políticas brasileiras para com países da África subsaariana parecem ter o mesmo objetivo.

Este artigo procurou explicar a estratégia geopolítica brasileira para o Atlântico Sul, desde o ano 2000. A hipótese era a de que o Brasil tem buscado o comando do oceano, através do controle de localidades estrategicamente significativas e através da limitação da influência de países extrarregionais, na região. Ela se confirma apenas parcialmente, porque o Brasil não tentou estabelecer bases militares em locais geopoliticamente importantes, tampouco questionou as possessões britânicas no Atlântico Sul. Iniciativas brasileiras apontam para uma estratégia geopolítica que visa a garantir sua soberania e independência, em vez de confrontar potências já estabelecidas. Tentativas de limitação da influência estrangeiras à região objetivam uma maior autonomia, não apenas para o Brasil em si, mas também para todos os países do Atlântico Sul considerados nesta pesquisa.

Como bem disse Corbett (1911), o comando do mar, em tempos de paz, é uma expressão retórica que significa que um país tem uma frota e posições navais adequadas para assegurar o comando, em caso de guerra. O Brasil não tentou adquirir posições navais fora de suas águas jurisdicionais, desde 2000. No entanto, a estratégia geopolítica brasileira visou a assegurar o comando local permanente da Amazônia Azul, i.e. proteger sua soberania e integridade territorial (por exemplo, através do SisGAAz e do PROSUB). Historicamente, potências extrarregionais ameaçaram e mesmo travaram guerras contra o Brasil, para conquistar territórios ou por motivos comerciais. Portanto, o principal objetivo do país é obter comando de suas próprias águas para que esses cenários não voltem a acontecer.

Depreende-se dessa estratégia que o Brasil tem uma postura defensiva, ainda que muito firme, em suas relações exteriores. O país resolutamente afirmou sua soberania e buscou mais 
independência vis-à-vis com potências extrarregionais presentes no Atlântico Sul, com as quais manteve relações cordiais, ainda que, às vezes, com um pé atrás. Dessa forma, a ascensão brasileira tem sido pacífica e, se depender do Brasil, ela permanecerá trilhando esse caminho.

\section{REFERÊNCIAS}

ABDENUR, A. E.; SOUZA NETO, D. M. de. O Brasil e a cooperação em defesa: a construção de uma identidade regional no Atlântico Sul. Revista Brasileira de Política Internacional, Brasília, v. 57, n. 01, p. 05-21, 2014.

ALBRECHT, S. Seemacht Brasilien?: Maritime Ambitionen einer aufstrebenden Macht im Südatlantik. Berlim: SWP, 2011.

ALBUQUERQUE, E. S. de. A geopolítica da dependência como estratégia brasileira de inserção no Sistema Internacional. OIKOS, Rio de Janeiro, v. 09, n. 01, p. 67-82, 2010.

ALENCASTRO, L. F. de. O Trato dos Viventes: formação do Brasil no Atlântico Sul. São Paulo: Cia. das Letras, 2000.

AMORIM, C. Brazilian Foreign Policy under President Lula (20032010): an overview. Revista Brasileira de Política Internacional, Brasília, v. 53, ed. Especial, p. 214-240, 2010.

Brasil, um país provedor de paz. Estudos Internacionais, Belo Horizonte, v. 01, n. 02, p. 127-137, 2013.

AQUINO, E. T. et alli. Interesses estratégicos brasileiros no Atlântico Sul: atividades na Elevação do Rio Grande. In: CONGRESSO ACADÊMICO DE DEFESA NACIONAL, 13., 2016, Rio de Janeiro. Disponível em: <http://www.defesa.gov.br/arquivos/ ensino_e_pesquisa/defesa_academia/cadn/artigos/XIII_cadn/ interesses_estrategicos_brasileiros_no_atlantico_sul__atividades_ na_elevacao_do_rio_grande>. Acesso em: 23 jan. 2017.

BANDEIRA, L. A. M. A importância geopolítica da América do Sul na estratégia dos Estados Unidos. Revista Espaço Acadêmico, Maringá, n. 89, p. 01-19, 2008. Disponível em: <http://www. espacoacademico.com.br/089/89bandeira.htm>. Acesso em: 09 set. 2016. 
Bruno Gomes Guimarães

BOHOU, J. Géopolitique et projection de puissance du Brésil au XXIe siècle. Paris: L'Harmattan, 2007.

BRASIL. Presidência da República. Política de Defesa Nacional, Brasília, 2005.

Ministério das Relações Exteriores. Relações com a África: Comércio e investimentos. Balanço de Política Externa 20032010, Brasília, 2010.

. Ministério da Defesa. Livro Branco de Defesa Nacional, Brasília, 2012.

ZOPACAS - Amorim propõe ações para fortalecer cooperação em defesa, Brasília, 2013. Disponível em: <https:// goo.gl/Kpjjym>. Acesso em: 9 out. 2014.

BRITES, P.; MARTINS, J. M. Q.; SILVA, A. M. M. O papel dos mísseis cruzadores de longa distância nas marinhas da Coreia do Sul e Japão: Lições para a Marinha do Brasil na defesa do présal no contexto do Atlântico Sul. In: SEMINÁRIO BRASILEIRO DE ESTUDOS ESTRATÉGICOS INTERNACIONAIS, 2013, Porto Alegre. Disponível em: <http://www.sebreei.eventos.dype.com. br/resources/anais/21/1371438486_ARQUIVO_OPAPELDOSMIS SEISCRUZADORESDELONGADISTANCIANASMARINHASDACORE IADOSULEJAPAO-LICOESPARAAMARINHADOBRASILNADEFESA DOPRE-SALNOCONTEXTODOATLANTICOSUL.pdf>. AcesSO em: 11 out. 2014.

CARVALHO, G. de L. C. O mar territorial brasileiro de 200 milhas: estratégia e soberania, 1970-1982. Revista Brasileira de Política Internacional, Brasília, v. 42, n. 01, s/p., 1999.

CASARÕES, G. S. P. A política externa interina e os riscos à integração regional. Conjuntura Austral, Porto Alegre, v. 07, n. 37, p. 81-93, 2016.

CASTRO, T. de. América do Sul: vocação geopolítica. Rio de Janeiro: Escola Superior de Guerra, 1997.

. Atlântico Sul: Geopolítica e Geoestratégia. Rio de Janeiro: Escola Superior de Guerra, 2002.

COMANDO do $3^{\circ}$ Distrito Naval participa da Operação "OBANGAME EXPRESS 2016". Marinha do Brasil, 2016. Disponível em: <https:// www.marinha.mil.br/node/973>. Acesso em: 9 out. 2016. 
CORBETT, J. Some principles of maritime strategy. Londres: Paperback, 1911.

FIORI, J. L.; PADULA, R.; VATER, Ma. C. (coord.). A projeção do Brasil na América do Sul e na África Subsaariana e o controle da Bacia do Atlântico Sul. Rio de Janeiro: UFRJ, 2012.

GOMES GUIMARÃES, B. Brazilian policy towards the South Atlantic: politics and strategy. Berlim; Potsdam: Freie Universität Berlin; Humboldt Universität; Universität Potsdam, 2015a.

A política brasileira para o Atlântico Sul: uma visão paradigmática. In: SEMINÁRIO INTERNACIONAL DE CIÊNCIA POLíTICA, 1., 2015b, Porto Alegre. Anais eletrônicos... Disponível em: <https://www.ufrgs.br/sicp/wp-content/uploads/2015/09/ GUIMAR\%C3\%83ES-A-pol\%C3\%ADtica-brasileira-para-oAtl\%C3\%A2ntico-Sul-SICP.pdf>. Acesso em: 23 jan. 2017.

GOMES GUIMARÃES, B.; SEBBEN, S. C.; DUARTE, R. F. A fronteira Brasil-Uruguai: desdobramentos do século XVIII ao XX. Revista Perspectiva, São Carlos, v. 04, p. 49-62, 2011.

IISS. The Military Balance 2013, Londres, 2013.

The Military Balance 2016, Londres, 2016.

KORNEGAY, F. A. South Africa, the South Atlantic and the IBSABRICS equation: the Transatlantic space in transition. Austral: Brazilian Journal of Strategy and International Relations, Porto Alegre, v. 02, n. 03, p. 75-100, 2013.

LESSA, A. C. A Guerra da Lagosta e outras guerras: conflito e cooperação nas relações França-Brasil (1960-1964). Cena Internacional, Brasília, v. 01, n. 01, p. 109-120, 1999.

MARTINS FILHO, J. R. O projeto do submarino nuclear brasileiro. Contexto internacional, Rio de Janeiro, v. 33, n. 02, p. 277-314, 2011.

Visões civis sobre o submarino nuclear brasileiro. Revista Brasileira de Ciências Sociais, São Paulo, v. 29, n. 85, p. 129224, 2014.

OLIVEIRA, L. K. de; CEPIK, M. A. C.; BRITES, P. V. P. O Pré-Sal e a segurança do Atlântico Sul: a defesa em camadas e o papel da integração sul. In: SEMINÁRIO BRASILEIRO DE ESTUDOS 
Bruno Gomes Guimarães

ESTRATÉGICOS INTERNACIONAIS, 2013, Porto Alegre. Anais... Porto Alegre: UFRGS, 2013.

OLIVEIRA, L. K. de et alli. Gripen NG: a decisão pela autonomia tecnológica e estratégica. Blog do Instituto Sul-americano de Políticas Estratégicas, Porto Alegre, 2013. Disponível em: <https://goo.gl/6XFKw9>. Acesso em: 9 out. 2016.

PAGLIARI, G. Conselho de Defesa Sul-Americano e a adoção de medidas de fortalecimento de confiança. Carta Internacional, Belo Horizonte, v. 10, ed. Especial, p. 23-40, 2015.

PENHA, E. A. Relações Brasil-África e geopolítica do Atlântico Sul. Salvador: EDUFBA, 2011.

PEREIRA, A. D. As relações entre África do Sul e Brasil: do impacto da globalização à constituição do IBAS. Século XXI, Porto Alegre, v. 01, n. 01, s/p., 2010.

PEREIRA DA SILVA, A. O novo pleito brasileiro no mar: a plataforma continental estendida e o Projeto Amazônia Azul. Revista Brasileira de Política Internacional, Brasília, v. 56, n. 01, s/p., 2013.

PETERSEN, M. Geopolitik im Südatlantik: Britische, FalklandIslands' oderargentinische ,IslasMalvinas'?. Tübingen: IMI, 2012. Disponível em: <http://www.imi-online.de/2012/07/12/ britische-falkland-islands-oder-argentinische-islas-malvinas/>. Acesso em: 10 nov. 2016.

PROENÇA, Jr., D.; DINIZ, E.; RAZA, S. G. Guia de estudos de estratégia. Rio de Janeiro: Jorge Zahar, 1999.

RAFFAELLI, M. A Guerra da Lagosta: um episódio das relações diplomáticas Brasil-França. Cadernos do CHDD, Brasília, ano II, n. $03, \mathrm{~s} / \mathrm{p} ., 2003$.

REZENDE, L. O Dissenso de Washington e a política externa de Temer e Serra. Carta Capital Internacional, 08 set. 2016. Disponível em: <https://goo.gl/57v9m6>. Acesso em: 11 set. 2016.

SANTAYANA, M. O cerco à indústria brasileira de defesa. Carta Maior, 7 out. 2015. Disponível em: <https://goo.gl/3P2Qjn>. Acesso em: 9 out. 2016. 
SILVA, A. L. R. da. Brasil, potência emergente: desafios do desenvolvimento e da inserção internacional. In: VIZENTINI, P. G. F. et alli (org.). BRICS: as potências emergentes. Petrópolis: Vozes, 2013.

SOARES, F. Ten. Marinha participa de operação internacional para capacitar países africanos no patrulhamento do Golfo da Guiné. Assessoria de Comunicação do Ministério da Defesa, 2015. Disponível em: <http://goo.gl/WWnf9N>. Acesso em: 9 out. 2016.

STOCHERO, T. Corte de verba faz Marinha suspender projeto para defesa do pré-sal. G1, 11 nov. 2015. Disponível em: <https://goo. gl/VjiqhB>. Acesso em: 9 out. 2016.

STUENKEL, O. Brazil, South American Regionalism and ReDefining the "Atlantic Space". In: KORNEGAY, F. A.; BOHLERMÜLLER, N. (Eds.). Laying the BRICS of a New Global Order: From Yekaterinburg 2009 to eThekwini 2013. Pretoria: African Institute of South Africa, 2013. p. 327-45.

VAZ, A. C. O Atlântico Sul e as perspectivas estratégicas de Brasil, Argentina e África do Sul. In: ACIOLY, L.; MORAES, R. F. (orgs.). Prospectiva, estratégias e cenários globais: visões de Atlântico Sul, África Lusófona, América do Sul e Amazônia. Brasília: IPEA, 2011. p. 49-59.

VIZENTINI, P. F. De FHC a Lula: uma década de política externa (1995-2005). Civitas: Revista de Ciências Sociais, Porto Alegre, v. 05, n. 02, p. 381-397, 2005.

Brazil: The Dialectical Nature of Security and Integration in South America. Policy: issues \& actors, Solna, v. 20, n. 09, s/p., 2007.

WIESEBRON, M. L. Blue Amazon: thinking the defense of Brazilian maritime territory. Austral: Brazilian Journal of Strategy and International Relations, Porto Alegre, v. 02, n. 03, p. 101-124, 2013. 